\title{
THE DEVELOPMENT OF SPEAKING SKILLS IN ENGLISH LANGUAGE LESSONS
}

The paper deals with the importance of teaching speaking skills in foreign language lessons and it compares theoretical backgrounds and objectives of language teaching with the reality observed at some primary and lower-secondary schools and gymnasia in the Zilina Region. It also presents the results of the research which prove that in the observed lessons, speaking skills were not developed sufficiently.

Key words: speaking skills, language habits, explicit knowledge, implicit knowledge, proceduralization, traditional techniques, learner-oriented activities.

\section{Introduction}

This article draws on the principles of teaching and learning foreign languages and on the proceduralization of explicit language knowledge - the process that learners need to go through in order to develop the communicative competence. In the research carried out in primary and secondary schools in the Zilina Region in Slovakia, we investigate if the classroom communication enables learners to proceed from gaining explicit language knowledge through gaining language habits to finally gaining implicit language knowledge which enables them to use language structures automatically in productive creativity. In this process of proceduralization, learners achieve the communicative competence which is the objective of language learning.

\section{Communicative Competence and Its Objectives}

The learner who achieves the communicative competence is able to use appropriate language in a given context of use, and has mastered a range of language structures and their functions ([6], p. 131). The communicative competence is usually defined in categories of four sub-competencies ([3], p. 147):

a) grammatical competence

b) sociolinguistic competence

c) discourse competence

d) strategic competence

In the Common European Framework ([2], p. 13), the sub-competences of the communicative competence are defined in terms of the linguistic, pragmatic and socio-linguistic competences. The linguistic competence includes "lexical, phonological, syntactical knowledge and skills and other dimensions of language as system, independently of the sociolinguistic value of its variations and the pragmatic functions of its realisations" ([2], p. 13). It is emphasised that "this component... relates not only to the range and quality of knowledge... but also to cognitive organisation and the way this knowledge is stored... and to its accessibility (activation, recall and availability)" ([2], p. 13). In other words, the learners need to gain not only the language knowledge, but also the strategies which are needed so that they become independent learners and independent users of the target language. The strategies also help them gradually turn the explicit knowledge of language structures into implicit knowledge which is readily available whenever needed.

Learners' communicative competence is further demonstrated through their socio-linguistic competence, which means that learners are able to respect social conventions in various social environments and communities. The pragmatic competence is "concerned with the functional use of linguistic resources (production of language functions, speech acts), drawing on scenarios or scripts of interactional exchanges. It also concerns the mastery of discourse, cohesion and coherence" ([2], p. 13). In this context, "the impact of interactions and cultural environments in which such abilities are constructed" ([2], p. 13) is of significant importance.

Achieving communicative competence is the objective which is stipulated in the Zakon o vychove a vzdelavani c. 245/2008 Z. z. ([13], p. 11), the document valid for all primary and secondary schools. The new educational law stresses the fact that the language is the means of thinking and communication among people and therefore, the process of learning a language should focus on the development of communicative competences. The main emphasis is placed on the productive creativity, which means that learners

\footnotetext{
* Danica Gondova

Faculty of Humanities, University of Zilina, Slovakia, E-mail: danica.gondova@fpv.uniza.sk
} 
should be encouraged to use the language creatively to express their own ideas, opinions, arguments or feelings.

\section{Achieving Communicative Competence in School Conditions}

In the light of the development of the communicative competence, we believe that effective language learning techniques are those which enable learners to achieve the objectives stipulated in the educational law, i.e. all components of the communicative competence. Language learning moves from declarative, explicit knowledge (such as grammar rules, grammatical forms, vocabulary) to its proceduralization (gaining implicit knowledge), i.e. the ability to use the language automatically and creatively when needed. Gaining declarative or explicit knowledge of language systems has definitely its meaning when the language is studied in school conditions because the language classroom is often the only space where the learner has the opportunity to encounter the target language. However, explicit knowledge is not sufficient, and it is also necessary to provide learners with opportunities to change their explicit knowledge into implicit through giving them space for multidimensional interaction so that they can gain language habits and subsequently secondary language skills ([5], p. 35) and competences. These are achieved in the process of proceduralization in which the explicit knowledge is changed into implicit, procedural knowledge.

It is also necessary to realize that in order to be taught language explicitly, learners need to be cognitively mature. Therefore, the younger the learners the less appropriate cognitive teaching is. It is generally accepted that at the primary level learners should acquire language, not learn it consciously. On the other hand, explicit teaching might be of great importance for adult learners, including upper-secondary students, whose cognitive thinking has been developed. Even though explicit learning might be helpful, having gained the explicit knowledge learners should be given adequate space to proceduralize the explicit knowledge in meaningful, communicative tasks. We would like to emphasize that it is not sufficient to let learners practise new language structures at sentence level in various grammatical exercises included in coursebooks. Learners also need to practise them in speaking tasks such as oral drills, or tasks including an information gap [11] which are meaningful and personalized. These tasks should be done in pairs or in small groups so that multi-dimensional communication is possible and the learner talking time is increased.

According to ([7], pp. 53-54) teachers in Slovakia proclaim that they use communicative tasks, but the results of her research prove that they put much more emphasis on declarative knowledge and they overestimate it. On the other hand, the learners express dissatisfaction with the fact that their secondary skills are not developed sufficiently. ([10], p. 58) achieved similar results in her research when she found out that students achieve better results in discrete-item tests than they do in language in-use-tests even though their teachers claim that they use communicative tasks in the teaching process.

\section{Kinds of Techniques and Activities}

In the 1960s, ([9], p. 3) divided techniques used in language teaching into manipulative and communicative. According to him, manipulative techniques are those in which the learner receives all the language from the teacher, the book or the cassette and his only task is to reproduce it. On the other side of the continuum, there are tasks which enable learners to use words and structures that they themselves choose, which means they also have to control meanings of their utterances.

At present, the techniques are divided in a similar way $[1,4$, 12]. The most important aspect is considered to be the level of language control by the teacher. On the one side of the continuum there are controlled techniques, often referred to as accuracy-oriented or systems-oriented techniques. The questions a learner is asked to answer or to respond to are all display questions ([1], p. 171) to which the answer is known in advance. These techniques usually focus on the correct form of the target structure, not on its use. They are teacher-oriented and highly structured. Learners' responses are predictable and the teacher's role is mainly that of a controller who controls not only what happens in the lesson, but also the language learners are asked to use.

Through predominantly controlled techniques and afterwards predominantly free techniques, learners proceed to the other side of the continuum to the techniques that are referred to as skillsoriented or fluency oriented techniques. Their main focus is the meaning and message of the communication. The questions are referential questions ([1], p. 171) and therefore, the language learners produce is not predictable. For this reason these techniques are considered to be communicative. The freer the language enabled by a technique the more learners can proceduralize their knowledge and gain secondary skills and communicative competence.

\section{Research Objectives}

This article is based on a larger research which we carried out from January 2010 till November 2010 and whose main objective was to find out if teachers at primary and secondary schools in the Zilina Region use techniques that lead to developing language habits and language skills, in other words techniques which are not controlled and which enable learners to produce language to express their own ideas, opinions and feelings. We observed forty five English lessons taught by fifteen English teachers (three lessons each) at primary, and lower and upper secondary schools (five teachers at each level).

For the purposes of our research we differentiate three groups of techniques which reflect the three above mentioned stages of language learning:

a) techniques helping learners gain explicit knowledge

b) techniques helping learners gain language habits

c) techniques helping learners gain secondary skills. 
In addition to that, within each of the groups we differentiate between traditional techniques and activities. We understand the traditional techniques as those which are teacher-oriented and done with the whole class. They do not allow independent, productive work of learners and do not allow productive creativity. On the other hand, activities are those tasks which enable learners to work independently from the teacher, and produce language to express their own ideas, feelings and opinions; they also make multi-dimensional interaction possible, and make learners think productively at all stages of language learning.

\section{The Speaking Skills of Primary and Secondary School Learners}

The main focus of this study is to discuss if the techniques and activities which we observed in the forty five lessons enable learners to gain speaking habits and secondary speaking skills, i.e. the skills which make it possible for them to speak the target language spontaneously, without too much thinking and too many hesitations, and without too much searching for words or sentence structures. Such techniques and activities support productive creativity and thus help learners achieve communicative competence.

As mentioned above, we observed English teachers teaching at three stages of schools. According to the new educational law [13] primary learners are supposed to achieve A1 level of the CEF ([13], p. 23), which means that they should be able to "produce simple mainly isolated phrases about people and places" ([2], p. 58). At the end of the lower secondary education, the learners should achieve at least A2 level of the CEF ([2], p. 23) and should be able to "give a simple description or presentation of people, living or working conditions, daily routines, likes/dislikes, etc. as a short series of simple phrases and sentences linked into a list" ([2], p. 58). Even though these two groups of learners are not expected to communicate freely or to produce a sustained monologue, they should be able to at least answer simple referential questions and have gained some language habits.

The third group of learners in our research includes Gymnasium students whose objective is to achieve B2 level. As to the speaking skills, the B2 learner is expected to "give clear, detailed descriptions and presentations on a wide range of subjects related to his/her field of interest, expanding and supporting ideas with subsidiary points and relevant example" ([2], p. 58). At B2+ level, the learner can "give clear, systematically developed descriptions and presentations, with appropriate highlighting of significant points, and relevant supporting detail" ([2], p. 58). In addition to that, the learner should also be able to "develop a clear argument, expanding and supporting his/her points of view at some length with subsidiary points and relevant examples" ([2], p. 59). In order to be able to do that, the learner must have a good command of secondary skills and strategies that lead to the mastery of a foreign language. Therefore, the learner must have not only been exposed to a variety of language input, but must also have had ample opportunities to practise language freely and creatively.

\section{Taxonomy of Techniques and Activities}

In order to be able to observe what happens in the lessons we worked out a taxonomy of techniques and activities on the continuum of controlled (accuracy-oriented) to free (fluency-oriented) techniques and activities. The controlled side of the continuum includes mostly techniques, whereas the free side of the continuum includes mainly activities. Before we carried out the actual research, we observed fifteen classes and worked out the taxonomy used in the research.

The observed categories were divided into four groups:

a) classroom management

b) controlled techniques and activities enabling gaining explicit knowledge;

c) semi-controlled techniques and activities enabling gaining language habits;

d) free techniques and activities enabling gaining secondary skills.

In the first group we included the time teachers spent on managing the class, e.g. doing the register, organizing learners, giving instructions or recording the results of learners' work. These do not contribute to the development of learners' language skills directly, but are a necessary part of the teaching process.

The second group consisted of accuracy-focused techniques and activities whose main objective was for learners to learn or acquire language structures or vocabulary items, or to practise pronunciation. Most of the whole-class techniques were 'heads-down' activities, which means learners were doing exercises from the course-book and writing the answers in them. They also included a lot of techniques where learners were asked to translate the English texts or exercises into Slovak and afterwards produce the answers. Using techniques teachers applied direct teaching strategies and explicit knowledge was taught deductively. On the other hand, the activities included in this group focused on teaching grammar or vocabulary inductively. They also included games which help learners remember new words or grammatical structure more easily. There is only one technique in this group which focuses on speaking directly and that is a (meaningful) drill done as a whole class task. It requires learners' oral response to a visual prompt or some information they get (e.g. flash cards, replacing words in sentences).

The third group includes mainly activities which stimulate learners to use language more independently in various problemsolving tasks, situational dialogues, meaningful drills, surveys, interviews, rehearsed role-plays, simulations or games. The objectives of these activities focus on practising target structures or vocabulary in meaningful, communicative activities done in pairs or in small groups. We have only included a few semi-controlled techniques in this group, such as retelling a story, or a monologue; a talk, description, or dialogue performed in front of the whole class after having rehearsed their performances in groups or in pairs. Most of these techniques or activities require oral or written production of language which is controlled only partly. 
The last group includes those activities in which learners use the target language freely to express their own ideas and opinions or to talk about their own experiences. They include such activities as brainstorming, group discussions, debates, problem-solving tasks, prediction tasks, projects, unrehearsed role-plays, interviews, surveys, icebreakers, etc. We also included some traditional techniques in this group, such as a whole-class discussion or interview led by the teacher. When doing the tasks included in the third group, learners gain the experience of practising a variety of speaking sub-skills, such as producing long and short turns in the interaction, turn-taking, negotiating the topic, keeping the conversation going, starting and terminating the turn, initiating the conversation, using discourse markers and conversational fillers, etc. ([1], p. 277)

\section{Research Results}

The results of the research show that the observed teachers paid very little attention to developing learners speaking skills. Primary teachers had fifteen lessons at their disposal, but they only taught 14 lessons and ten minutes (they started the lesson later or finished earlier than they were supposed to). Out of this time, 6 minutes 44 seconds were spent on drills (group 2), and during another 21 minutes 46 seconds, teachers asked individual learners to produce a short talk, description or dialogue without giving them a chance to prepare for it in a small group before. That means the learners spent $4.5 \%$ of the classroom time they had at their disposal to develop their speaking habits. It is necessary to stress though, that these were all techniques which means that only one learner was talking at a time and everybody else was just listening to him/her without actually having any reason to listen because no task was set.

Speaking was practised even less at lower-secondary schools. Learners spent 9 minutes 35 seconds doing whole-class drills; during another 1 minute 50 seconds, some of them were producing a talk or a description; and during another 8 minutes 57 seconds, teachers were asking referential questions to the whole class. All in all, the duration of the teaching time was 14 lessons and 32 minutes, 48 seconds; and out of this time, $3.07 \%$ was spent on techniques which required speaking from learners. The observed teachers teaching at primary and lower secondary schools did not use any activities and did not encourage any multidimensional communication in pair or group activities.

At upper secondary schools, we also video-recorded 15 lessons; and the teachers used 14 lessons, 27 minutes, 38 seconds to teach. Out of this time, learners spent 2 minutes 2 seconds doing drills; 52 minutes 52 seconds answering teacher's referential questions asked to the whole-class; another 10 minutes 55 seconds talking, describing or producing a dialogue in front of the whole class without having any opportunity to rehearse it in a small group before. In other words, $10.01 \%$ of the allocated time was spent doing speaking tasks which, however, were teacher-oriented. That means some learners had the opportunity to try and say something, the others did not develop their speaking habits because they were just listening.
Upper-secondary school learners were also involved in some speaking activities: in some lessons learners were asked to work in pairs and do meaningful drills during 5 minutes, 9 seconds; they spent another 5 minutes 46 seconds discussing a fictitious situation in pairs or in small groups, and another 4 minutes, 29 seconds discussing a real situation in pairs or in small groups. In this way, these learners spent additional $2.34 \%$ of the allocated time practising speaking and gaining speaking habits.

Out of 15 observed upper secondary school teachers, one asked students to brainstorm ideas - an activity that lasted for 85 seconds and subsequently, they were asked to discuss a topic in groups of three people using any language they could and expressing their ideas on the topic. These were the only two activities which enabled learners to practise their secondary speaking skills. These activities took 2 minutes 25 seconds, which is $0.58 \%$ of the overall time spent on free communicative activities in which students can develop their speaking skills.

Altogether, in the observed lessons, learners spent $0.93 \%$ of the time doing teacher-oriented drills; $3.18 \%$ answering teacher's referential questions in a whole-class task; $1.75 \%$ doing another teacher-oriented task - describing something, talking about something or performing a dialogue in front of the whole class. Only upper-secondary learners were asked to work in pairs or in small groups to practise speaking in order to gain speaking habits. These activities took $0.78 \%$ of the overall time of the observed lessons. Free speaking lasted for only $0.2 \%$ of the overall time.

As we have already mentioned above, we observed 45 English lessons. The real time of the lessons taught was 117,266 seconds, which was 43 forty-five-minute lessons, 19 minutes, 43 seconds. Out of this time, only $6.84 \%$ of the time was spent on practising speaking.

\section{Discussion}

At present, "language teaching is being shaped by several important ideas. First, the shift toward a cognitive paradigm means that learning has taken precedence over teaching. What the student learns is the important outcome of the teaching-learning process, not what the teacher teaches" ([8], p. 379). Learners learn much more if they can do things themselves and this is particularly true about learning skills. One cannot master a skill without trying it out, practising it and improving it consistently.

The research shows that when teaching English, the observed teachers direct their attention, as well as the attention of their learners, to the development of the learners' linguistic competence, emphasizing teaching mainly grammar and vocabulary. Teaching pronunciation is not the focus of their attention. A lot of attention is also paid to reading, particularly to reading unknown texts aloud. Most teachers use mainly direct teaching strategies, and most of the teaching we observed was up-front teaching with teachers doing a lot of talking, very often in Slovak. Because the ratio of teacher talking time was very high in comparison to student talking time, 
students had very few opportunities to speak and learn from speaking.

The issue of the value of teacher and student talking time is very complex. Learners need to be given opportunities to produce language in real time interactions in order to be able to acquire speaking sub-skills such as those mentioned above: producing short and long turns in conversations, taking turns, negotiating a topic, keeping the conversation going; producing talks in various situations, etc. In addition to that, when they speak they are given opportunities to notice their own mistakes and learn from them to be able to develop their interlanguage. This did not happen in the observed lessons because learners did not have sufficient space to practise speaking, and most of the speaking activities we could observe included short answers to teachers' questions.

As we have mentioned above, A1 and A2 learners are not expected to produce much spoken language independently, yet they should be able to answer teacher's questions about their families, places of living, likes and dislikes, or everyday experiences. At A2 level they should also be able to produce simple descriptions and a sustained monologue. In the lessons they should practise these in various situational dialogues, role-plays, interviews or simulations. However, in real life the observed learners only answered teacher's display questions and the speaking tasks they did were usually not learner-oriented and therefore only one or two people could speak during that time. What we found very surprising was that the observed teachers at primary and lower-secondary schools used only very few games and meaningful drills, and did not use any situational dialogues, role-plays, or simulations which might make it possible for children to acquire some speaking skills. Instead, children spent most of the time doing grammar and vocabulary tasks, and in many cases they had to 'digest' quite a lot of metalanguage to be able to do the required grammatical tasks.

The situation is not better in the observed lessons in gymnasia either. The observed teachers spent most of the time doing traditional, whole-class tasks without giving learners opportunities for productive creativity, i.e. expressing their own ideas, opinions, arguments, etc. This happens despite the fact that at B1-B2 levels learners are expected to produce quite a lot of spoken language in interactions spontaneously. We believe that this is one of the reasons why students can perform fairly well in written tests, but their speaking skills are below the required level.

The research results illustrate that the learners at the observed schools have very few opportunities to practise speaking, which necessarily means that they do not gain any speaking habits, or speaking skills. Moreover, in most cases the output they produce is very restricted and they are not given a chance to develop their procedural knowledge in productive, creative tasks. We believe that giving learners opportunities for productive creativity is a necessary pre-condition of gaining the communicative competence which is the objective stipulated in the new educational law.

In addition to the observations we also carried out interviews with all the observed teachers to find out how they understand the teaching/learning process and how they perceive what happens in their classrooms. The observations revealed that teachers do not give learners sufficient space to develop their speaking skills, but despite that teachers consider speaking and the ability to communicate as the most important part of foreign language learning. They also emphasise the necessity for the learners to gain communicative competence. Eight of the observed teachers believe that in their lessons, learners have sufficient space to practise and develop their speaking skills; two teachers believe that the space is rather limited, and five teachers admit that it is not sufficient. Eleven teachers claim that their learners are not interested in developing their speaking skills and when they are asked to work in pairs or in small groups, they usually speak Slovak.

The teachers' answers also revealed that most of them are familiar with the principles of the learner-oriented approach to language teaching, but are not ready to give up their role of a controller. Some of them do not know how speaking skills can be practised through accuracy-oriented activities at low levels of language proficiency, and fluency-oriented activities at higher levels of language proficiency. Despite the fact that the communicative approach to language teaching/learning has existed for about forty years, most of the observed teachers still rely on the grammar-translation method. Surprisingly, this is true not only for all unqualified English teachers, but also for those who have the required qualifications.

We believe that learners' skills will not improve if English becomes a compulsory subject and will be taught from Year 3 at primary schools. On the contrary, if it is taught in the way we could often observe in the 45 lessons, learners will not understand the communicative function of the language; they will not perceive it as a means of communication, but only as another school subject. Instead of developing speaking skills, they will develop inhibitions and will not be confident about using the target language. We believe that in order to achieve the objectives of the latest school reform it is necessary to change teachers' perception of and their approach to foreign language teaching.

\section{Acknowledgement}

This research was supported by the grant KEGA n. 085ŽU4/2011 of the Ministry of Education, Science, Research and Sport of the Slovak Republic.

\section{References}

[1] BROWN, H. D.: Teaching by Principles. An Interactive Approach to Language Pedagogy. London: Longman, 2001.

[2] Common European Framework. 2007. [cit. 2008-10-25]. http://www.coe.int/t/dg4/linguistic/Source/Framework_EN.pdf 
[3] COULTHARD, M.: An Introduction to Discourse Analysis. London: Longman, 1985.

[4] HARMER, J. The Practice of English Language Teaching. London: Longman, 2004.

[5] CHODERA, R., RIES, L.: Teaching Foreign Languages on the Eve of the New Century I. (In Czech: Vyuka cizich jazyku na prahu noveho stoleti I). Ostrava: Ostravska univerzita, 1999.

[6] LARSEN-FREEMAN, D.: Techniques and Principles in Language Teaching. New York: Oxford University Press, 2000.

[7] LOJOVA, G.: The Theory and Practice of Teaching Foreign Language Grammar (In Slovak: Teoria a prax vyucovania gramatiky cudzich jazykov.). Bratislava: Monitor Promotion, 2004.

[8] LYNNE, T.: A Course for Teaching English Learners, New York: Pearson Education, Inc., 2008.

[9] PRATOR, C.: Development of a Manipulation - Communication Scale. Education Resources Information Centre. [citované 2009-02-23] http://www.eric.ed.gov/ERICWebPortal/custom/portlets/recordDetails/detailmini.jsp?_nfpb=true\&_\&ERICExtSearch_SearchV alue_0=ED041258\&ERICExtSearch_SearchType_0=no\&accno=ED041258

[10] RAFAJLOVICOVA, R.: Testing Verb Forms through Descrete-point and Open-ended Tasks. Presov: Presovska univerzita, Fakulta humanitnych a prirodnych vied. 2000. ISBN 80-8068-002-7.

[11] REES, G.: Find the Gap - Increasing Speaking in Class. In Teaching English. British Council, BBC, 2003. [citované 2009-01-24]. http://www.teachingenglish.org.uk/think/articles/find-gap-increasing-speaking-class

[12] SCRIVENER, J.: Learning Teaching. Oxford: Macmillan Education, 2005.

[13] The Educational Law No 245/2008 Z. z. (In Slovak: Zakon o vychove a vzdelavani c. 245/2008 Z. z., Bratislava: Ministerstvo skolstva SR, 2008 [cit. 2008-11-08]. http://www.minedu.sk/data/USERDATA/Legislativa/Zakony/245_2008.pd. 